\title{
EFL students' perception on flipped learning in writing class
}

\author{
Akhmad Fauzan \\ a_fauzan@edu.upr.ac.id \\ Universitas Palangka Raya \\ Jalan Yos Sudarso, Palangka Raya, 73111, Indonesia \\ Maria Novary Ngabut \\ mary.ngabut@gmail.com \\ Universitas Palangka Raya \\ Jalan Yos Sudarso, Palangka Raya, 73111, Indonesia
}

Received: February 23, 2018; Accepted: September 14, 2018; Published: September 20, 2018

\begin{abstract}
This research aims at finding out EFL students' perceptions on the implementation of Flipped Learning in writing class. Survey research was applied with one-shot design and questionnaire was used to collect data. The setting of this research is at one university in Central Kalimantan Province in Indonesia where English is a foreign language. The students were in their fourth semester learning writing skill. In order to avoid teacher-centered learning which may cause a boring and monotonous classroom, this research implemented Flipped Learning that could change the way students learn. The approach was done during one semester and the questionnaires were then handed out at the end of the semester. After the questionnaires were collected and analyzed quantitatively and qualitatively, the result of this research shows that students had positive perceptions on the implementation of Flipped Learning in Writing 3 class.
\end{abstract}

Keywords: Flipped Learning, EFL classroom, writing skill, Indonesia

How to cite this paper: Fauzan, A., \& Ngabut, M. N. (2018). EFL students' perception on flipped learning in writing class. Journal on English as a Foreign Language, 8(2), 115-129. doi:http://dx.doi.org/10.23971/jefl.v8i2.792

DOI: http://dx.doi.org/10.23971/jefl.v8i2.792 
Flipped Learning is a pedagogical approach in which direct instruction moves from the group learning space to the individual learning space, and the resulting group space is transformed into a dynamic, interactive learning environment where educator guides students as they apply concepts and engage creatively in the subject matter (Flipped Learning Network, 2014). In other words, Flipped Learning can be defined as an in-class activity that is done at home and home work that is done at school (Hwang, Lai, \& Wang, 2015, p. 450). Therefore, this approach can give chance for teachers to be creative in the classrooms by applying many kinds of activities and the classroom time can be directed towards active and collaborative learning (Roach, 2014, p. 75).

In flipping the classrooms, teachers can make online materials containing of those that should be presented traditionally in front of the class, by uploading it to video hosting websites; while the class time can be used for various learning activities (Simpson \& Richards, 2015, p. 163). Further, the flipped-classroom model of teaching can move out the content that fits in the lower levels of Bloom's Taxonomy (remembering and understanding) to be done outside of class, thus reserving in-class time for the higher order levels, such as applying, analyzing, evaluating, and creating (See \& Conry, 2014, p. 585). As a result, in the classroom the lecturer can provide immediate feedback concerning misconceptions or gaps in students' knowledge thus empowering students to reach higher levels of Bloom's taxonomy (O'Flaherty \& Phillips, 2015, p. 87-88).

By implementing Flipped Learning, students signified that they could adapt well to the learning process, so they felt more responsible to themselves (Simpson \& Richards, 2015, p. 165). Students also like the ability to work at their own pace and time and are able to apply what they learn in the classroom and throughout the course (Gilboy, Heinerichs, \& Pazzaglia, 2015, p. 112). Furthermore, students agree that the class time interaction is helpful to their understanding of course concepts and perceive that the flipped classroom activities are more student-oriented than traditional class activities (Kim, Kim, Khera, \& Getman, 2014, p. 41-42).

In order to successfully implement Flipped Learning, The Flipped Learning Network (2014) states the four pillars of F-L-I-PTM . The first pillar is that it allows Flexible Environment. It means teachers can make adjustment to learning materials, learning activities, and time of studying. Teachers can manage which activity to fit the lesson. As a result, students can have flexible time and place to study (Chen, Wang, Kinshuk, \& Chen, 2014, p. 18). The second pillar is the variation of Learning Culture. By having this, it can focus on how the students should learn inside and outside of classrooms. In Flipped Learning, students are given chances to learn by themselves so they can 
generate manner as independent learners. Through this approach, students can adjust their pace to explore topics in depth thus guide themselves to additional resources and have various learning activities (McLaughlin \& Rhoney, 2015, p. 13). The third pillar is the freedom of Intentional Content. Flipped Learning allows teachers to determine what materials they have to teach online and in the classroom. The chances of avoiding teacher-centered may happen as teachers can maximize the classroom time for various student-centered activities, depending on the level of education and the subjects. Teachers can modify it based on the needs and interests of the students as well as the dynamics of the classroom (Basal, 2015, p. 34). Finally, the fourth pillar is about Professional Educator. Teachers should be professional when they implement the Flipped Learning approach. It can be in the way of providing on-going assessment towards students' progress and giving feedback onto students' works. Even though the teachers' role may be little in this approach, but they play important part to make this approach occurs. Thus, teachers should facilitate students to reach learning outcomes (van Vliet, Winnips, \& Brouwer, 2015, p.2).

There have been several research conducted on the implementation of Flipped Learning in language classrooms. Bell (2015) investigated the student and teacher attitudes and beliefs about learning German in flipped learning approach. Bell conducted the research within one semester where the activities in the classroom were not intended for grammar materials, yet to enable students to achieve language learning objectives based on the American Council on the Teaching of Foreign Languages (ACTFL) Proficiency Guidelines developed for four language skills and the Standards for Foreign Language Learning in the 21st Century (SFLL) (NSFLP, 2006) by employing various activities, assignments, and projects (Witten, 2013). The results showed that students gained comfort during the in-class activities and felt confidence because they can adjust their time in learning outside of the classroom. Another research in language classroom was conducted by Evseeva and Solozhenko (2015) in which they attempted to evaluate the efficiency of the flipped classroom technology in the process of teaching and learning the English language at a technical university. Their research objectives were to evaluate the efficiency of the flipped classroom in teaching and learning the English language, to overview the concept of the flipped classroom technology in the educational process, and to focus on the advantages that the flipped classroom can provide. The results of the research based on the survey showed that $85 \%$ of students regarded the integration of flipped classroom technology into the learning process, while the other $15 \%$ of respondents were not inspired because they encountered problems, such as internet access, lack of time for completing 
online assignments, and difficulty with self-discipline to organize their work properly. From the articles related to flipped learning, it is rare to find articles conducted on the implementation of Flipped Learning in EFL context, particularly in Indonesia. Therefore, this research tries to fill the gap.

At the level of university, the instruction in the classroom should allow students to be critical thinkers, independent learners, and able to synthesize theories. Furthermore, students are expected to show their English language capability. In Writing 3 class at the English Education Study Program of Universitas Palangka Raya, students are expected to have theoretical and practical knowledge on various kinds of texts at junior and senior high schools (English Education Study Program, 2016, p. 15). Since the content of the material in Writing 3 course is touching two domains, the cognitive and psychomotor, then it is important to balance the portion of theory and practice in the classroom. However, if the classroom activity is allotted for theory, then there will not be enough time for writing practice, and vice versa. Based on the lecturer's experience when he taught the course in the previous years, he experienced that the time allocated in the classroom was mainly for explaining theories before the class thus there was not enough time for the writing activity. It became a teacher-centered classroom because the focus is on the teacher as the teacher does most of the talking and students listen, while the students primarily work alone and the classroom is quiet (Jonson, Cappelloni, \& Niesyn, 2011, p.131). As a result, this practice has caused the class to be boring and monotonous. The disadvantage of teacher-centered approach is mainly on the teaching and learning process which becomes passive, as a result of the students' low interest and motivation in learning, their inability of relating the content of the materials, and their ability to digest information (Jonson, et al., 2011, p.131). This phenomenon is also on the contrary to the requirements of

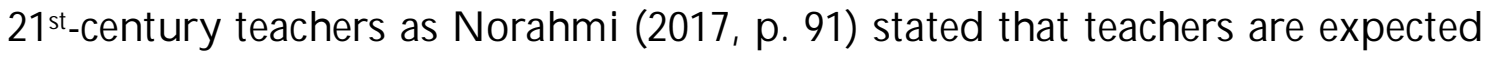
to be competent, professional, up-to-date, and technology-based due to the students' ability to get information faster.

In 2017, one of the lecturers of Writing 3 class, who is one of the researchers in this research, considered there should be a change in the classroom activity in which that the time in the classroom can be used for discussion, exploring learning materials, and writing practice, as well as providing feedback to students' assignments and projects. Based on the information mentioned above, in an EFL classroom at a university level, there should be a learning model which can accommodate the knowledge deepening as well as allow the students to improve their language skills. Thus, the learning model that can fit this is Flipped Learning. 
Through Flipped Learning, it is expected that the time in the classroom can be used for exploring topics in greater depth and creating richer learning opportunities. Besides, students can learn the instructional materials at home at the time they feel convenient. Therefore, based on the research background above, the researchers implemented Flipped Learning approach into EFL classroom, which is Writing 3 class, and investigated Writing 3 students' perceptions on the implementation of Flipped Learning in English as a foreign language classroom.

This research aims at finding out EFL students' perceptions on the implementation of Flipped Learning in writing class. The result of this research is expected to support the improvement of English teaching and learning in EFL countries and to contribute to the enrichment of flipped learning theories.

\section{METHOD}

The kind of research that the researchers chose to investigate Writing 3 students' perceptions on the implementation of Flipped Learning in English as a foreign language classroom is Survey Research. This kind of research was chosen because the researchers needed to gather data related to attitudes and opinions (Ary, Jacobs, \& Sorensen, 2010, p. 414). The design of this research is One-Shot Survey Design as the researchers were to determine the current perception of one group at one point in time (Lodico, Spaulding, \& Voegtle, 2010, p. 202). Therefore, the instrument of this research was questionnaire and it was used to collect information from groups of individuals, in this case is students, and it permits the researchers to summarize or to measure their attitudes and opinions towards some issue (Ary et al., 2010, p. 28).

The questionnaire contained statements related to activities outside and inside the classroom, and the effectiveness of flipped learning in EFL class. It was developed by adopting Likert Scale, so there were five options to respond to every statement (Strongly Disagree, Disagree, Neutral, Agree, and Strongly Agree). Each statement has blank space for the students to write their opinion or reason. Although survey research is believed to be a wholly quantitative approach (Julien, 2008, p. 846), this research applied both quantitative and qualitative approach. The reason for employing both approaches is because the researchers distributed questionnaires which contain close-ended and openended questions. The close-ended questions that provide numerical data were analyzed based on quantitative approach, while the open-ended questions that provide narrative responses were analyzed based on qualitative approach (Julien, 2008, p.846).

The setting of this research was at the English Education Study Program of Universitas Palangka Raya, Indonesia. This study program produces future 
English teachers for secondary schools especially in Central Kalimantan Province. The instructions in the classrooms are using both Indonesian and English language. The subject of this research was chosen by purposeful sampling because the selection of participants was based on who has key knowledge or information related to the purpose of the study (Lodico et al., 2010, p. 34). The subject of this research was all the students of Writing 3 in Group B at the English Education Study Program of Universitas Palangka Raya in academic year 2016/2017. There were 34 students in the class and they were in their fourth semester at the university. The researchers considered that these students fitted to the need of this research because they were regarded to be mature in age and aware of learning. Besides, the researchers decided that they were the ideal population so all these students received the survey.

In order to collect the data for this research, the questionnaire was distributed at the end of the semester because the flipped learning approach was conducted the whole semester. After the students filled in the questionnaire, they submitted it back to the researchers. The questionnaires were then analyzed by calculating the percentage of each aspect of the Likert Scale (Strongly Disagree, Disagree, Neutral, Agree, and Strongly Agree). Next, the researchers sought for interesting values, which is the highest numbers or unexpected numbers. The researchers also read the responses on each item and sought for interesting comments that could give notion towards the implementation of flipped learning in writing class.

\section{FINDINGS}

Based on the questionnaire (Appendix 1), the researchers presented the findings in form of percentages and students' answers on each item.

From item number 1,58.82\% students agreed that they can adjust the time of learning when they have to learn outside of the classroom; while there are $32.35 \%$ strongly agreed to this. One student (A27) stated that "Because I can choose the time when I feel enjoy to study". However, there are $8.82 \%$ students who are neutral to this statement as they think that they still experienced difficulties in adjusting the time to study outside of the classroom.

Statement number 2 is about the students' opinion if learning outside of the classroom is convenient. $47.06 \%$ students agreed and $29.41 \%$ students strongly agreed. One student (A3) responded that studying material outside of the classroom enables me to concentrate more. I enjoyed my learning style and I did not feel bothered by other things. Most of the students agreed as they can adjust the time when they want to study and concentrate more on the lesson without any distraction. However, there are $20.59 \%$ students who are neutral and there is one student who disagreed to this because when they encountered 
difficult materials when learning outside of classroom they did not know where to seek answers.

For the statement number 3, students gave their opinion on their commitment to learning outside of the classroom to improve themselves. $55.88 \%$ students agreed and $26.47 \%$ students strongly agreed by saying that commitment is necessary otherwise they will not learn anything and cannot improve themselves. On the contrary, $17.65 \%$ students show neutral opinion and one student (A24) said that I chose neutral because I do not have commitment to study. I study if I do not have any other activities. This student admitted that $\mathrm{s}$ he does not have the commitment to learning as s/he learns only when s/he does not have any activity. This can be caused as some students have work during their study.

When the students have to give their opinions on statement number 4, $58.82 \%$ students agreed and $38.24 \%$ students strongly agreed that classroom activity was used effectively for exploring materials. Student A12 stated that when we were in the classroom, we always produced written task, worked in groups, and developed projects. It made us explore the materials. Further, we were guided and supervised by the lecturer so that the classroom activities could be used to explore the materials effectively. The students agreed that when they were in the classroom, they always did the writing assignment, creating projects, and exploring the materials. Further, the presence of the lecturer in the classroom could help the students to explore the materials effectively.

In item number 5, 61.76\% students agreed that classroom activity was used effectively for creating richer learning opportunities in form of individual work, group work, task analysis, and presentation. In addition, 35.29\% students strongly agreed as A32 stated that because from doing a classroom activity effectively, I can learn how to give a good presentation in my class, and learn how to analyze a text, and create a good team work in a group.

Based on item number 6, 52.94\% students agreed that the classroom activity allowed them to write good texts. However, $23.53 \%$ students were neutral as they think that the classroom activity is not about enhancing their writing skills but more on increasing writing knowledge. Student A15 said that because it is rare to writing texts in the classroom activity. In fact, the lecturer had balanced the portion of writing activity and discussion in the classroom.

Statement number 7 is about how the classroom activity allowed the lecturer to give feedback to students' writings or projects. $55.88 \%$ students strongly agreed to it, while $41.18 \%$ students agreed as student A11 said because from feedback by the lecturer, I can do my writing/project be better again, and I 
also can know where is my mistakes when I do it then I can change it be better project.

For statement number 8, students gave their opinion on how the implementation of Flipped Learning was effective in Writing 3 class. $47.06 \%$ students agreed and $41.18 \%$ strongly agreed. However, $11.76 \%$ were neutral as A17 stated since there are several students who did not understand the material well, they did not perform maximally in the classroom activities. There are others who did not encounter any hindrance to study individually out of the classroom, and they could perform the classroom activities well. This student admitted that there were some students who did not fully understand the materials while there are others who performed better.

When the students have to state their opinion on item number 9, the same number of students $(44.12 \%)$ agreed and strongly agreed that Flipped Learning requires lecturer's professionalism. Student A10 stated in order to deliver the right materials and to provide corrections and feedback to students' writings, a professional lecturer is needed. Based on this statement, the student stated that a professional lecturer is needed to give feedback and input on students' writings.

Finally, on item number 10, 29.41\% agreed, 26.47\% strongly agreed, $5.88 \%$ disagreed, and $38.24 \%$ students were neutral. Student A4 chose Neutral because they stated that there are some EFL classes that require guides from the lecturers. Not all knowledge is applicable without lecturer's control. However, for Writing 3 class, it is considered to be effective. According to this statement, Flipped Learning may or may not be applicable to all EFL classes, yet it was effective in Writing 3 class.

\section{DISCUSSION}

Based on the result of the questionnaires, most of the students responded Agree and Strongly Agree to all the statements in the questionnaires. However, there are very minor numbers on Neutral, Disagree, and Strongly Disagree. The positive responses from the students is then considered as the indictor that the Flipped Learning was successfully implemented in Writing 3 class since the lecturer (one of the researchers) had followed the four pillars of F-L-I-PTM as follow.

The first is making Flexible Environment. During the semester, the lecturer sent the materials to students' e-mails and encouraged them to access online materials and videos on the internet. In the classroom, the lecturer varied learning activity, such as individual writing, group writing, and project presentation. The students studied the materials outside the classroom and there was a week period for the students to study each material from today's 
meeting to the following meeting. During the learning process, the lecturer observed and monitor students' progress through assignments and projects. As a result, students become more engaged with course materials (le Roux \& Nagel, 2018, p. 25), well-prepared and perform better (Gross, Pietri, Anderson, Moyano-Camihort, \& Graham, 2015, p. 7).

The second pillar of Flipped Learning is about Learning Culture. In order to vary the learning activities in the classroom, Scientific Approach, Cooperative Learning, and Project-based Learning were implemented in the classroom as these learning approaches are regarded to fit perfectly in Writing 3 class. During the semester, students were given opportunities to actively engaged in their own learning and progressively improve their mastery over the course content (Moraros, Islam, Yu, Banow, \& Schindelka, 2015, p. 7). It is believed that the blend of students' individual learning styles and the class environment contributed to students' learning outcome (AlJarrah, Thomas, \& Shehab, 2018, p. 12).

The third pillar relates to Intentional Content. In Writing 3 class, students should learn about Texts which cover Interpersonal Text, Transactional Text, Short Functional Text, and Long Functional Text, then the lecturer taught the concept of a text (Eggins, 2004, p. 56), such as register configuration (field, tenor, mode), schematic structure (structure of text), and realizational patterns (words and structures to express in language). As the students understand the concept of a text, they can further identify and analyze the other kinds of texts. Flipped Learning also has given opportunities to students to work through difficult materials during classroom activities (Koskinen, Lämsä, Maunuksela, Hämäläinen, \& Viiri, 2018, p. 6).

The last pillar is on Professional Educator. During the course, the lecturer provided feedback in real time in the classroom for students' individual and group assignments and projects. The lecturer also conducted observation and reflection in order to decide the practice for each meeting of the course. Supervised classroom activities result in increased and more effective learning (Nouri, 2016, p. 9). Further, discussion among teacher and students can enhance classroom interactions and help create a supportive learning environment (Lee \& Lai, 2017, p. 13).

All in all, from the results of the questionnaire, it is obvious that the students positively perceived that Flipped Learning was effectively implemented in the class. They agreed that switching classroom environment can give new nuance to the learning activity. They could adjust their learning time at the time they felt convenient even though it required their commitment to study. In the classroom, they could explore the materials effectively as they had various learning experiences such as individual work, group work, text 
analysis, and project presentation. They were also given feedback so that they could produce a well-written composition.

\section{CONCLUSION}

The implementation of Flipped Learning in EFL class, in this case is Writing 3 class, had shown that it was implemented successfully as most students responded positively on the questionnaire. Besides, students' scores are satisfactorily as they could submit well written writing projects and did the midterm and final test well. The researchers agreed to say that there are many benefits that students get during this research. The students were given opportunity to adjust their learning time when they were not in the classroom so that they felt that learning outside of the classroom is convenient. The students have improved themselves in terms of commitment in learning alone without lecturers' attendance or guidance. Furthermore, the students could explore further the learning materials as they had learned it at home so they could continue learning in the classroom. As a result, the students could have richer learning experience, such as individual work, group work, text analysis, and presentation. Finally, the students could produce well written writing projects because they got feedback on every assignment they had from the lecturer.

Based on this research, the researchers would like to recommend several ideas for further improvement of Flipped Learning in EFL class. First, Flipped Learning is effectively implemented when students have commitment to learn. It would require students' maturity that they need to study otherwise they would not gain any knowledge. Second, Flipped Learning requires various online learning materials and lecturers may make use available materials on the internet or develop their own. Third, Flipped Learning requires lecturers' professionalism as the lecturers should be able to work both online and offline, provide feedback onto students' projects either individual or group work in real time, and give scores to the projects in time. Last thing to remember, Flipped Learning may or may not be suitable for EFL classrooms and it, therefore, needs further research on different content or skill subjects.

\section{REFERENCES}

AlJarrah, A., Thomas, M. K., \& Shehab, M. (2018). Investigating temporal access in a flipped classroom: procrastination persists. International Journal of Educational Technology in Higher Education, 15(1), 1-18. https://doi.org/10.1186/s41239-017-0083-9

Ary, D., Jacobs, L. C., \& Sorensen, C. K. (2010). Introduction to research in education ( $8^{\text {th }}$ ed.). Belmont, CA: Wadsworth Cengage Learning. 
Basal, A. (2015). The implementation of a flipped classroom in foreign language teaching. Turkish Online Journal of Distance Education, 16(4), 28-37. http://dx.doi.org/10.17718/tojde.72185

Bell, T. R. (2015). The flipped German classroom. Paper presented at The 2015 Central States Conference on the Teaching of Foreign Languages, Minneapolis, USA. Retrieved from https://ssctfl.wildapricot.org/resources/Documents/2015Report/CSCTFL \%20Report_2015.pdf

Chen, Y., Wang, Y., Kinshuk, \& Chen, N. (2014). Is FLIP enough? Or should we use the FLIPPED model instead? Computers and Education, 79(-), 16-27. http://http://dx.doi.org/10.1016/..compedu.2014.07.004

Eggins, S. (2004). An introduction to systemic functional linguistics $\left(2^{\text {nd }} e d.\right)$. London, UK: Continuum International Publishing Group.

Evseeva, A. \& Solozhenko, A. (2015). Use of flipped classroom technology in language learning. Paper presented at XV International Conference "Linguistic and Cultural Studies: Traditions and Innovations", LKTI 2015, 9-11 November 2015, Tomsk, Russia. https://doi.org/10.1016 j.sbspro.2015.10.006

Flipped Learning Network (FLN). (2014). The four pillars of F-L-I-PTM. Retrieved from https:/flippedlearning.org/wpcontent/uploads/2016/07/FLIP_handout_FNL_Web.pdf

Gilboy, M. B., Heinerichs, S., \& Pazzaglia, G. (2015). Enhancing student engagement using the flipped classroom. Journal of Nutrition Education and Behavior, 47(1), 109-114. http://dx.doi.org/10.1016/j.jneb.2014.08.008

Gross, D., Pietri, E. S., Anderson, G., Moyano-Camihort, K., \& Graham, M. J. (2015). Increased preclass preparation underlies student outcome improvement in the flipped classroom. CBE Life Sciences Education, 14(4), 1-8. https://doi.org/10.1187/cbe.15-02-0040

Hwang, G., Lai, C., \& Wang, S. (2015). Seamless flipped learning: A mobile technology-enhanced flipped classroom with effective learning strategies. Journal of Computers in Education, 2(4), 449-473. https://doi.org/10.1007/s40692-015-0043-0

Jonson, K., Cappelloni, N., \& Niesyn, M. (2011). The new elementary teacher's handbook: Flourishing in your first year ( $3^{\text {rd }}$ ed.). Thousand Oaks, CA: Corwin.

Julien, H. (2008). Survey research. In L. M. Given (Ed.), The Sage Encyclopedia of Qualitative Research Methods (Vol 1 \& 2). Thousand Oaks, CA: Sage.

Kim, M. K., Kim, S. M., Khera, O., \& Getman, J. (2014). The experience of three flipped classrooms in an urban university: An exploration of design 
principles. Internet and Higher Education, 22(1), 37-50. http://dx.doi.org/10.1016/).iheduc.2014.04.003

Koskinen, P., Lämsä, J., Maunuksela, J., Hämäläinen, R., \& Viiri, J. (2018). Primetime learning: collaborative and technology-enhanced studying with genuine teacher presence. International Journal of STEM Education, 5(1), 1-13. https://doi.org/10.1186/s40594-018-0113-8

le Roux, I., \& Nagel, L. (2018). Seeking the best blend for deep learning in a flipped classroom - Viewing student perceptions through the community of inquiry lens. International Journal of Educational Technology in Higher Education, 15(1), 1-28. https://doi.org/10.1186/s41239-018-0098-x

Lee, K., \& Lai, Y. (2017). Facilitating higher-order thinking with the flipped classroom model: A student teacher's experience in a Hong Kong secondary school. Research and Practice in Technology Enhanced Learning, 12(1), 1-14. https://doi.org/10.1186/s41039-017-0048-6

Lodico, M. G., Spaulding, D. T., \& Voegtle, K. H. (2010). Methods in educational research: From theory to practice ( $2^{\text {nd }}$ ed.). San Francisco, CA: Jossey-Bass.

McLaughlin, J. E., \& Rhoney, D. H. (2015). Comparison of an interactive elearning preparatory tool and a conventional downloadable handout used within a flipped neurologic pharmacotherapy lecture. Currents in Pharmacy Teaching and Learning, 7(1), 12-19. https://doi.org/10.1016/j.cptl.2014.09.016

Moraros, J., Islam, A., Yu, S., Banow, R., \& Schindelka, B. (2015). Flipping for success: evaluating the effectiveness of a novel teaching approach in a graduate level setting. BMC Medical Education, 15(1), 1-10. https://doi.org/10.1186/s12909-015-0317-2

National Standards in Foreign Language Education Project (NSFLP). (2006). Standards for foreign language learning in the 21st century (3rd ed.). Alexandria, VA: Author.

Norahmi, M. (2017). 21 $1^{\text {st }}$ Century teachers: The students' perspectives. Journal on English as a Foreign Language, 7(1), 77-96. http://e-journal.iainpalangkaraya.ac.id/index.php/jefl/article/view /538/667

Nouri, J. (2016). The flipped classroom: for active, effective and increased learning - especially for low achievers. International Journal of Educational Technology in Higher Education, 13(1), 1-10. https://doi.org/10.1186/s41239016-0032-z

O'Flaherty, J., \& Phillips, C. (2015). The use of flipped classrooms in higher education: A scoping review. Internet and Higher Education, 25(1), 85-95. http://dx.doi.org/10.1016/).iheduc.2015.02.002 
Program Studi Pendidikan Bahasa Inggris. (2016). Kurikulum dan silabus 2016 Program Studi Pendidikan Bahasa Inggris. Palangka Raya: Universitas Palangka Raya.

Roach, T. (2014). Student perceptions toward flipped learning: New methods to increase interaction and active learning in economics. International Review of Economics Education, 17(-), 74-84. http://dx.doi.org/10.1016/.iree.2014.08.003

See, S., \& Conry, J. M. (2014). Flip my class! A faculty development demonstration of a flipped-classroom. Currents in Pharmacy Teaching $\mathcal{E}$ Learning, 6(4), 585-588. http://dx.doi.org/10.1016/.cptl.2014.03.003

Simpson, V., \& Richards, E. (2015). Flipping the classroom to teach population health: Increasing the relevance. Nurse Education in Practice, 15(3), 162167. http://dx.doi.org/10.1016/j.nepr.2014.12.001

van Vliet, E. A., Winnips, J. C., \& Brouwer, N. (2015). Flipped-class pedagogy enhances student metacognition and collaborative-learning strategies in higher education but effect does not persist. CBE Life Sciences Education, 14(3), 1-10. https://doi.org/10.1187/cbe.14-09-0141

Witten, H. (2013). World languages. In J. Bretzman (Ed.), Flipping 2.0: Practical strategies for flipping your class. New Berlin, WI: The Bretzman Group.

\section{Authors' Brief CV}

Akhmad Fauzan is a lecturer at Universitas Palangka Raya (UPR), Indonesia. He has taught at English Education Study Program since 2005. His research is mainly on English teaching and learning as foreign language in Indonesian context.

Maria Novary Ngabut is a lecturer at Universitas Palangka Raya (UPR), Indonesia. She has taught at English Education Study Program since 2008. Her research is mainly on linguistics of local languages and applied linguistics on English language teaching and learning.

\section{Appendix}

\section{QUESTIONNAIRE}

You have received this survey as part of a research study. The purpose of this study is to investigate student perceptions of the implementation of Flipped Learning in EFL classroom. This survey was designed to gather your beliefs about the benefits and disadvantages towards Flipped Learning and how its implementation has influenced

Journal on English as a Foreign Language, 8(2), 115-129

Copyright (C 2018 by JEFL, p-ISSN 2088-1657; e-ISSN 2502-6615 
your learning experience. Your responses are confidential and will not be shared with anyone in any way that identifies you as an individual. Only aggregated data will be presented in the final report. Your participation to this survey is completely voluntary and will not affect your grades. Your time and cooperation are greatly appreciated. If you have any questions regarding this survey or the study in general, please contact Akhmad Fauzan, English Education Study Program of Universitas Palangka Raya.

Please give tick mark $(\sqrt{ })$ to options that fit to your beliefs and provide reasons.

\begin{tabular}{llccccc}
\hline No & \multicolumn{1}{c}{ Statement } & $\begin{array}{c}\text { Strongly } \\
\text { Disagree }\end{array}$ & Disagree & Neutral & Agree & $\begin{array}{c}\text { Strongly } \\
\text { Agree }\end{array}$ \\
\hline 1 & $\begin{array}{l}\text { I can adjust the time of } \\
\text { learning when I have to } \\
\text { learn outside of classroom. }\end{array}$ & 0 & 0 & 3 & 20 & 11 \\
\cline { 2 - 6 } & Reason: & 0 & 1 & 7 & 16 & 10 \\
\hline 2 & $\begin{array}{l}\text { Learning outside of } \\
\text { classroom is convenient. }\end{array}$ & $(0.00 \%)$ & $(2.94 \%)$ & $(20.59 \%)$ & $(47.06 \%)$ & $(29.41 \%)$ \\
\hline \begin{tabular}{l} 
Reason: \\
\hline 3
\end{tabular} & $\begin{array}{l}\text { Learning outside of } \\
\text { classroom requires my } \\
\text { commitment to improve } \\
\text { myself. }\end{array}$ & $(0.00 \%)$ & $(0.00 \%)$ & $(17.65 \%)$ & $(55.88 \%)$ & $(26.47 \%)$ \\
\hline
\end{tabular}

\section{Reason:}

\begin{tabular}{llccccc}
4 & $\begin{array}{l}\text { Classroom activity was } \\
\text { used effectively for } \\
\text { exploring materials. }\end{array}$ & 0 & 0 & 1 & 20 & 13 \\
\hline
\end{tabular}

\section{Reason:}

5 Classroom activity was used effectively for creating richer learning opportunities (individual work, group work,

$\begin{array}{lllll}0 & 0 & 1 & 21 & 12\end{array}$
analysis, presentation).

\section{Reason:}

6 Classroom activity 0 1 8 allowed me to write good 


\begin{tabular}{llccccc}
\hline No & \multicolumn{1}{c}{ Statement } & $\begin{array}{c}\text { Strongly } \\
\text { Disagree }\end{array}$ & Disagree & Neutral & Agree & $\begin{array}{c}\text { Strongly } \\
\text { Agree }\end{array}$ \\
\hline \multirow{2}{*}{ texts. } & $(0.00 \%)$ & $(2.94 \%)$ & $(23.53 \%)$ & $(52.94 \%)$ & $(20.59 \%)$ \\
\cline { 2 - 4 } & & & & & 19 \\
\hline $7 \quad \begin{array}{l}\text { Classroom activity } \\
\text { allowed the lecturer to } \\
\text { give feedback to my } \\
\text { writing/project. }\end{array}$ & $(0.00 \%)$ & $(0.00 \%)$ & $(2.94 \%)$ & $(41.18 \%)$ & $(55.88 \%)$ \\
\hline
\end{tabular}

\section{Reason:}

\begin{tabular}{llccccc}
\hline 8 & $\begin{array}{l}\text { Flipped Learning was } \\
\text { effectively implemented in } \\
\text { Writing 3 class. }\end{array}$ & 0 & 0 & 4 & 16 & 14 \\
& Reason: & $(0.00 \%)$ & $(0.00 \%)$ & $(11.76 \%)$ & $(47.06 \%)$ & $(41.18 \%)$ \\
\hline 9 & $\begin{array}{l}\text { Flipped learning requires } \\
\text { lecturer's professionalism. }\end{array}$ & 0 & 0 & 4 & 15 & 15 \\
& $(0.00 \%)$ & $(0.00 \%)$ & $(11.76 \%)$ & $(44.12 \%)$ & $(44.12 \%)$ \\
\hline Reason: & 0 & 2 & 13 & 10 & 9 \\
\hline 10 & $\begin{array}{l}\text { Flipped Learning is } \\
\text { effective for EFL } \\
\text { classrooms. }\end{array}$ & $(0.00 \%)$ & $(5.88 \%)$ & $(38.24 \%)$ & $(29.41 \%)$ & $(26.47 \%)$ \\
\hline
\end{tabular}

\section{Reason:}

